\title{
Movilidades: derechos en conflicto
}

\author{
Mariflor Aguilar
}

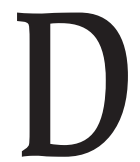

ice Paul Virilio, filósofo y urbanista francés: "El sedentarismo y el nomadismo han cambiado de naturaleza... El sedentario, en todas partes está como en su casa, con el celular y la computadora, igual que en el elevador, en los aviones o en el tren de alta velocidad... El nómada es el que en ninguna parte se siente en casa”.

Virilio y el cineasta Raymond Depardon, montaron el último invierno en la Fundación Cartier de París la exposición "Tierra natal”, la cual interroga sobre la capacidad de arraigo que tienen hoy los seres humanos, y sobre su capacidad de quedarse en algún lado. Incluso la noción misma de "tierra natal" es cuestionada, pues como se dice en el comentario que presenta la exhibición, la movilización migratoria -que se estima que en el año 2050 ascenderá a 200 millones de personas obligadas a reubicarse-cuestiona al mismo sedentarismo.

La exhibición constaba de tres partes, en tres salas distintas. En una sala con un piso peraltado haciendo las veces de asientos, se proyectaban datos y estadísticas en una pantalla redonda envolvente; en otra sala, haciendo gala innecesaria de moderna tecnología, colgaban del techo cincuenta pantallas en hileras; una hilera mostraba a Paul Virilio caminando por París exponiendo sus teorías sobre la globalización, ${ }^{1}$ y otra, mostraba imágenes de éxodos y movilizaciones, todas ellas desesperadas.

La parte destacada de la exposición es el diálogo entre dos pantallas también circulares, creación de Depardon; en una daban testimonio nueve habitantes sobrevivientes de pueblos originarios que narran entre llanto y su lengua entrecortada, sus pérdidas: pueblo, comunidades, tierra, compañía, y una dice: "sólo vivimos de la lengua". De los entrevistados, dos eran de Chile, dos de Bolivia, dos de Brasil, dos de Francia y uno de Etiopía.

${ }^{1}$ Como reseña Pilar Chapin en su blog el 12 de febrero de 2009. http://deuxfrontieres.blogspot.com/2009/02/raymond-depardon-paul-virilio.html. 
En la otra gran pantalla se proyectaban dos tipos de imágenes: unas son secuencias, en cámara rápida, de flujos ansiosos de gente caminando en ropa de playa por la calle de varias ciudades-resorts del mundo, acerca de lo cual el espectador se entera solamente por los letreros de los locales en los diferentes idiomas correspondientes; el otro grupo de imágenes, editadas vertiginosamente, son de playas atestadas de vacacionistas a la búsqueda de un metro cuadrado de sol, o aplicándose el bronceador para disfrutar el metro cuadrado encontrado o por encontrar. La noticia de que las imágenes de este segundo grupo también corresponden a varias playas del mundo, es más difícil de obtener, pero al fin se logra por los rasgos físicos que el camarógrafo tuvo a bien enfocar en close-up al menos en una ocasión en cada playa.

El diálogo que se entabla en las dos pantallas entre lo perdido y lo ganado es inquietante: lo perdido es narrado como tragedia por una sola persona en cada caso, un sobreviviente, enmarcado por paisajes límpidos fotografiados con tonos firmes y brillantes. Esta narración cinematográfica contrasta con lo ganado: multitudes ansiosas, reiterativas e impersonales cuya naturaleza se refleja en la fotografía de tonos grises y en la edición cuya velocidad sólo deja sentir la ansiedad que se encierra en formas turísticas de vivir las vacaciones.

Cuando se habla de los desplazamientos humanos en el planeta, el turismo tiene un lugar central y es un factor decisivo de la movilidad social, pero en contra de las representaciones comunes de esta esfera de relaciones sociales, según las cuales es donde se realizan los sueños, este ámbito de prácticas tiene otra cara. Destacar esto es, desde mi punto de vista, uno de los logros más señalados de la exposición "Tierra natal", ya que ese diálogo entre pantallas obliga a reflexionar y a formular preguntas acerca de la relación directamente proporcional entre turismo y despojo; acerca del carácter necesario o arbitrario de esta relación, en sus aspectos económico-políticos, éticos y ambientales, y a imaginar opciones $u$ otras posibilidades de pensar el turismo.

Y en un plano más abstracto y general de reflexión, también se puede pensar en el hecho mismo de la movilidad social en general y en la emergencia de élites cuya movilidad es apabullante.

La movilidad, el desplazamiento, vertiginoso o no, deseado o forzado, realizado o soñado, marcan nuestro tiempo. Hoy todo es o se quiere móvil. Desde los años noventas del pasado siglo Jacques Attali previó, en su ya clásico trabajo llamado Milenio (1990), que el XXI sería el siglo de los nómadas. El término nómada, dice: "es la palabra clave que define el modo de vida, el estilo cultural y el consumo de los años 2000. Pues entonces todos llevarán consigo toda su identidad: el nomadismo será la forma suprema del orden mercantil”. Según esto, no sólo los grupos humanos se caracterizan por ser nómadas, sino que lo son porque la fase actual de la producción de mercancías se orienta a producir 'objetos nómadas' que acompañan a los nómadas humanos; son productos que 
acompañan al humano y que le permiten estar completamente comunicado al mismo tiempo que estar en el más intenso movimiento. Son objetos cada vez más pequeños que los hace bienes fácilmente transportables que pueden acompañar al 'hombre nómada' que caracteriza a la época actual. ${ }^{2}$

Estudios recientes sobre la movilidad señalan que "la capacidad de determinar la movilidad corpórea de uno mismo o de otros es una forma tan importante del poder en las sociedades móviles, que tal vez sea hoy la forma más significativa del poder..."3 Al respecto, Deleuze y Guattari sugirieron que Occidente ha transitado en los últimos tiempos de sociedades disciplinarias a-la-Foucault, a sociedades de control en las que las relaciones están basadas en la desterritorialización. Por su parte, Zigmund Bauman se refiere a estas sociedades como a "sociedades pospanópticas organizadas en torno de un concepto interesante que es el de 'modernidad líquida'". 4

La movilidad puede verse como una dimensión existencial del ser humano: como un impulso vinculado con la libertad; también como una condición presente en todos los momentos del desarrollo de la humanidad que la ha conducido a poblar el planeta y a buscar mejores condiciones de vida. Son también flujos migratorios del orden económico-político vinculados con la atracción que ejerce el capital sobre ríos de mano de obra barata; o bien, son desplazamientos del orden científico y profesional debido a la concentración de polos de investigación de punta o de gran inversión tecnológica que atrae flujos profesionales de alta especialización. Dentro de cada una de éstas, y de otras formas de movilidad humana, individual y grupal, hay a la vez gran variedad de movilidades que se pueden agrupar en múltiples divisiones. En conjunto se vuelve un tema que abarca aspectos de espacio, de territorio y medio ambiente, aspectos socio-económicos y políticos, así como la dimensión del cuerpo, del deseo y de la proyección humana. Es quizá por eso que se considera que si los desplazamientos y movilidades humanas son probablemente el asunto que define nuestro tiempo, debe también atenderse el estudio de las formas que adquiere la acción de viajar, sus implicaciones y bases sociales, y sus transformaciones.

Vale la pena dar algunas cifras. Sólo en el año 2000, y considerando únicamente desplazamientos aéreos, se registraron 698 millones de llegadas de pasajeros, y se predice un billón para el 2010; medio millón de cuartos de hotel se construyen al año en el mundo; en cualquier momento del día hay 300000 pasajeros volando sobre Estados Unidos, lo equivalente a una ciudad impor-

\footnotetext{
${ }^{2}$ Jacques Attali, Milenio. México, Seix Barral, 1990, p. 81.

${ }^{3}$ John Urry, "Mobility and Proximity", en Sociology, vol. 36, núm. 2, British Sociological Association, Sage Publications, 2002, p. 264.

${ }^{4}$ Ibid., p. 267.
} 
tante. Es de interés, por otra parte, el lugar que tiene el viajar en la proyección subjetiva de los ciudadanos de algunas naciones. Se afirma que en la cultura estadounidense los individuos han incorporado como algo natural la idea de que tienen derecho a viajar; pero más aún, se incorpora también el viaje como un mandato: hay que viajar, hay que hacer del viaje una parte fundamental de la vida. ${ }^{5}$ Así como se ha dicho que en la actualidad global el mandato del amo es el goce, tal vez podría añadirse que una parte importante de este goce está ligado al mandato de moverse, de salir, de irse a otros lados; y como nómadas que todos somos -o queremos ser-, respondemos casi siempre al mandato, y nos vamos a otros lugares donde también podamos sentirnos en casa.

Cuando se habla de viajar lo que se entiende de manera inmediata es hacer turismo; pero viajar es más que eso. Se han distinguido diversas causalidades de los viajes efectivos, o sea, lo que se llama corporeal travel, para distinguirlos de la internet o de la misma imaginación. Según sus causales, los desplazamientos se separan en seis grandes grupos: a un grupo pertenecen obligaciones ${ }^{6}$ básicamente de tipo laboral y familiar; a otro, obligaciones sociales, como establecer vínculos humanos que requieren el cara-a-cara; otro grupo es el llamado de obligaciones temporales, relacionado con el tiempo que se requiere invertir para desarrollar un vínculo humano; el de obligaciones locales, relacionado con sentir un lugar directamente, como caminar en una ciudad, visitar un determinado edificio, estar en la orilla del mar, etcétera; ${ }^{7}$ el de obligaciones vivenciales, que se refiere a tener la experiencia en vivo y no mediada de un determinado evento, ya sea político, artístico o cultural. Un grupo más, al que le llama de obligaciones de objeto, se refiere a desplazamientos que se hacen por exigencia de estar cerca de algo sobre lo cual se está trabajando, como puede ser el caso de observar el modo de vida de una comunidad o el desarrollo de una tecnología determinada.

Lo interesante es que siendo tantas y tan disímiles todas estas diferentes movilidades, participan de algo en común que refiere a la proximidad fisica en su aspecto -digamos- socio-antropológico, que es la co-presencia, o la necesidad humana de tener un acercamiento o un conocimiento corpóreo y vivencial del mundo.

Detenerse en la distinción entre los distintos tipos de desplazamientos o de formas de viajar puede resultar interesante y esclarecedora, pero de momento me interesan sólo tres grupos: dos de los mencionados y uno que no se mencionó. De los mencionados, quiero referirme al de las obligaciones locales y al de las obligaciones vivenciales. Estos dos grupos tienen algunos rasgos en común:

\footnotetext{
${ }^{5}$ Ibid., p. 257.

${ }^{6} \mathrm{~J}$. Urry da a las motivaciones de viaje el extraño nombre de obligations.

${ }^{7}$ Ibid., p. 262.
} 
son quizá los que reúnen las movilidades a las que habitualmente se les llama turísticas; son también, y por ello mismo, los que se refieren a movilidades cuya causal o motivación, por imperiosa que sea, se acerca de hecho más a lo que puede ser el gusto o el deseo, que a la obligación.

Esto hace de estas prácticas algo realmente importante para el equilibrio y estabilidad de los individuos en sociedad. La posibilidad de descanso, de disfrute y de tener satisfacciones no estrictamente ligadas a las necesidades apremiantes de la sobrevivencia es muchas veces condición para que los individuos desarrollen sentimientos de autoestima y de aprecio por sus semejantes, así como aspectos creativos de sus habilidades personales y/o comunitarias.

Hablando de las heterotopías, que tienen la propiedad de yuxtaponer en un único lugar real distintos espacios, dice Foucault que "muy recientemente, se ha inventado una nueva heterotopía crónica, a saber, las ciudades de vacaciones; esas ciudades polinesias que ofrecen tres semanas de una desnudez primitiva y eterna a los habitantes urbanos". ${ }^{8}$

Las vacaciones son promesa de enfrentarnos a una parte nuestra siempre pospuesta, promesa de lo inesperado y diferente que puede dar cauce al deseo. Es tan esencial la dimensión del deseo, que es de lo que menos se sabe y de lo que la filosofía no ha podido dar cuenta. La filosofía contemporánea se ha preocupado algo más de esta materia, pero en la filosofía clásica son sobre todo dos los grandes pensadores que concedieron explícita y directamente al deseo un lugar central en sus reflexiones. Uno es Spinoza, quien considera al deseo como la esencia humana; el otro es Hegel, quien identifica al deseo con la razón, como el principio permanente de la autoconciencia. De una forma más o menos indirecta, Nietzsche sería el gran tratadista de las pasiones humanas, y quien en algún sentido provocó el interés que se tuvo por el deseo sobre todo entre los pensadores de la segunda mitad del siglo Xx. El deseo, vestido de voluntad, ocupa el centro: "La voluntad de potencia más que deseo de algo es deseo de desear... en última instancia lo que amamos es nuestro deseo, no lo deseado". 9 Los habitantes urbanos volcamos nuestro deseo a la promesa que nosotros mismos somos.

Acerca de las movilidades turísticas en las que el gusto y el deseo están presentes de manera explícita, John Urry señala que también en el caso de estas prácticas el impulso que está detrás es la necesidad de presencia. Es interesante que en el caso de estas movilidades, y de ninguna de las mencionadas, las telecomunicaciones no fueron suficientes para saciar la necesidad

${ }^{8}$ Michel Foucault, "Los espacios otros".

${ }^{9}$ Dice Roberto Castro citando y comentando a Nietzsche. En Freud mentor, trágico y extranjero: aproximaciones al pensamiento freudiano. http://books.google.com. $\mathrm{mx} /$ books. 
de cierto tipo de encuentros. Es así que los llamados "territorios móviles" son aquellos en los que se genera la duplicidad de la movilidad, la movilidad al cuadrado: la corpórea y la virtual, las cuales guardan entre ellas una relación de complementariedad, sirviéndose de estímulo y refuerzo recíproco, sin entrar en cambio en ningún tipo de relación de alternativa excluyente o de competencia. ${ }^{10}$

La relevancia político-económica del turismo tiene, por otro lado, tanta importancia como su aspecto psicosocial. Cualquiera que sea la búsqueda específica de quien viaja para darse el gusto, lo cierto es que el turismo es un factor decisivo de la movilidad social y un sector social que debe atenderse. Además de captar el 10\% del empleo global total, los turistas son hoy un grupo social privilegiado y consentido, ya que es para ellos, para atraerlos, por lo que se rearticulan los planes de desarrollo y se llevan a cabo reestructuraciones territoriales regionales, nacionales y en ocasiones mundiales. Teniendo al turismo en la mira, se planea la "redistribución" de lo que aún faltaba privatizar, territorios que conservan su valor biológico, estético, de recursos naturales y algunas veces comunitario.

Del turismo se habla siempre desde el punto de vista de las economías nacionales, pero no tanto desde el punto de vista político, desde el que ahora quiero verlo. El punto al que quiero ir es a destacar que estos lugares, donde se cumplen los compromisos móviles con el descanso, la relajación, y eventualmente con el disfrute, en ocasiones coinciden y se complementan con otras movilidades, con las que dije que no estaban en la lista mencionada de movilidades posibles; estas otras son movilidades involuntarias, no son como las que integran el primer grupo, el de las obligaciones laborales y familiares de las que se dice que "se tiene que ir al trabajo" o "se tiene que ir a la boda de un familiar". No, a las que me refiero son movilidades no deseadas, que van en contra de la voluntad de quienes se desplazan, quienes no pueden decir que "tienen que irse" como si se tratara de atender un compromiso previamente contraído, sino que "tienen que irse" porque no les queda más remedio, esto es, por los desastres "naturales", por "reestructuración territorial" o por la imposibilidad de tener una vida digna; tienen que irse porque a veces los obligan sin saber las causas reales por las que deben abandonar su lugar.

Así se presenta esta otra forma de movilidad que aparentemente es complementaria al turismo, aunque sería más correcto decir que tienen una relación complementaria/antagónica. Antagónica, desde la perspectiva de los que se marchan; complementaria desde la perspectiva del Estado que opera como

${ }^{10}$ Además de lo señalado por Urry, hay quizá otra dimensión social de la subjetividad que puede encontrarse a la base de cierto tipo de turismo, que es la necesidad de pertenencia, y en este caso, pertenencia a las franjas sociales con algún prestigio. 
organizador para que la partida de unos complemente el descanso y la riqueza de otros, regulando y desregulando de tal forma que unos dejen libre el espacio a los que siempre están presentes cuando de ganancias se trata. La asimetría entre las movilidades es patente: unos son movilizados o tienen que hacerlo, para que otros lleguen por gusto y tengan la experiencia... de caminar por el valle o ver con sus propios ojos el paisaje, o como sugieren Virilio y Depardon, para que busquen desesperados un metro cuadrado para tomar el sol.

Se dirá y se dice que en los países cuyo desarrollo se ha visto obstaculizado, atraer al turismo es una forma de creación de empleos. Pero aquí entra en juego otro de los mitos de la globalización: que los empleos adecuados para los países del llamado "tercer mundo", son los empleos de servicios y no cualquier otro que suponga o implique alguna forma de autonomía. Los proyectos populares o comunitarios no son tomados en cuenta en la numerología de la economía nacional oficial.

Se sabe: de lo que se trató el reciente gran conflicto de la Amazonia peruana es de abrirla a las inversiones privadas y "adaptar la legislación peruana al Tratado del Libre Comercio firmado el año pasado con Estados Unidos", ${ }^{11}$ lo cual bien se justifica, ya que como dice la propaganda: "La cuenca del Amazonas es un paraíso para el turismo, ecoturismo y turismo de aventura". Si así se hiciera, si se llegaran a imponer los decretos privatizadores, lo que se afectaría es la mayor biodiversidad del planeta para, según se dice, sacarla del atraso y llevarles el progreso, un progreso que como se señaló en una de las mesas del primer día del Foro, no coincide con la idea de "buen vivir" o del sumak kausai de los indios peruanos, ni con otras nociones de "buen vivir".

Se sabe también que otras regiones del mundo enfrentan la misma situación: en Chile, Argentina y Brasil. En México, es parte del Plan Nacional de Desarrollo, y el cuarto eje del Plan de Gobierno "Chiapas solidario", hacer un corredor ecoturístico, multiplicar por tres los turistas para incrementar el ingreso de divisas, o como dice la propaganda "hacer de la tierra de Chiapas el paraíso para las inversiones extranjeras".

Desde muchos puntos de vista, la importancia de estos programas es innegable. La "obligación" o el derecho, pero al fin la demanda humana de presenciar lugares o de vivir heterotopías crónicas es una legítima inclinación que, como veíamos, comienza a integrarse como elemento estructural de ciertas culturas. Pero es evidente, por otro lado, que este requerimiento creciente en las sociedades modernas entra en conflicto con otra demanda o derecho legítimo de quienes habitan en los futuros corredores turísticos, que es el de permanecer en sus territorios. 2009

${ }^{11}$ Iván Restrepo, "La lucha por la Amazonia", en La Jornada. México, junio de 
Esto plantea un reto importante a las sociedades y a los Estados modernos, que consiste en lograr que dos dimensiones tan centrales y legítimas de la naturaleza humana como son la capacidad de asombro y su realización, por un lado, y la dignidad, por otro, no entren en conflicto, incorporando en sus políticas públicas apoyos a proyectos populares autogestivos, o bien formas de atracción del capital que no vayan contra intereses de quienes habitan un territorio y quieren permanecer en él, tomando en cuenta que muchos desplazamientos que habrían podido evitarse, han devenido en pérdidas dramáticas de calidad de vida. 